\title{
FRONTIER IMAGERY IN GENTRIFICATION NARRATIVES: ANDREW WINGFIELD'S SHORT STORY CYCLE RIGHT OF WAY (2010)
}

\begin{abstract}
A b s t r a ct. This paper investigates Andrew Wingfield's use of the frontier myth in the short-story cycle Right of Way (2010), set in a contemporary urban neighborhood undergoing gentrification. Using Frederick Jackson Turner's notion of the frontier and the Chicago School's urban ecology as a theoretical backdrop, I explore the ways in which Wingfield both deploys and challenges the imagery of the frontier and the invasion-succession model of the ecological paradigm. I argue that, while the frontier myth most likely appeals to the Americans' self-identity as a nation, Wingfield uses the myth as the warp on which to weave a nuanced picture of the new urban frontier, with a focus on micro-level interactions and attachments that produce a sense of place.
\end{abstract}

Keywords: frontier myth; gentrification; invasion-succession; urban ecology; sense of place.

Place implies space, and each home is a place in space. Space is a property of the natural world, but it can be experienced. From the perspective of experience, place differs from space in terms of familiarity and time. A place requires human agency, is something that may take time to know, and a home especially so. As we move along the earth we pass from one place to another. But if we move quickly the places blur; we lose track of their qualities, and they may coalesce into the sense that we are moving through space.

Robert Sack, Homo Geographicus 1997, 16

Andrew Wingfield's short-story cycle Right of Way is structured around the production of space through gentrification. The spatial processes in Cleave Springs, a fictional Washington, D.C. neighborhood, are typical of the economic

ANETA DyBSKa, PhD, Habil., University of Warsaw, Institute of English Studies; address for correspondence: ul. Hoża 69, 00-681 Warsaw, Poland; e-mail: adybska@uw.edu.pl; ORCID: https://orcid.org/0000-0002-5239-713X. 
growth and decline cycles that reinscribe urban geographies in a capitalist city. The gentrification stories revolve around the displacement of ethnic working-class populations by members of the creative class, ${ }^{1}$ who bring with them new notions of place authenticity linked to spaces of consumption, and a particular taste and style. They appreciate the historical houses in the neighborhood, their design, and decorative work but less so the place's urban vernacular culture (Zukin 3). In the transforming physical environment, where blight and renovation coexist, new social relationships and interconnections emerge, investing places with new meanings and emotions. Speaking to the shared experience of American urban dwellers, the Right of Way stories evoke a sense of place, defined by human geographers as "subjective meanings that become attached to a location and the physical landscape that is characteristic of that location" (Cresswell 356). Though individual biographies, memories, and emotional attachment to place account for each character's unique environmental past, ${ }^{2}$ Wingfield frames the old-timer/newcomer interactions within the recognizable cultural symbolism of the frontier myth. He achieves the place's appealing immediacy by combining urban ecological explanations with a sensitivity to differential power relations involved in gentrification.

\section{INVASION-SUCCESSION}

Although in the last decades revisionist historians of the American West have challenged Frederick Jackson Turner's thesis on the "The Significance of the Frontier in American History" (1893), the myth of the frontier is wellnested in the American popular imagination as a source of the nation's history and social evolution. As seen by Turner, the frontier was a geographical space, "an edge of free land" beyond which lay the vast expanses of territory open to colonization, to settlement, to development," "the meeting point between savagery and civilization," a "belt, including Indian country and the outer margin of the

\footnotetext{
${ }^{1}$ Richard Florida coined the term creative class in reference to professionals employed in knowledge-based industries and creative economies of the post-industrial era. Among them were scientists, engineers, architects, university professors, financiers, legal and healthcare professionnals, writers, designers, artists, entertainers, editors, and bohemians. Florida maintained that the creative class was the engine of place-based regeneration and their presence in the declining industrial centers would stimulate local economies. See Florida's The Rise of the Creative Class, 2002.

${ }^{2}$ Human geographers define environmental past in the context of an individual's place identity as "a past consisting of places, spaces and their properties which have served instrumentally in the satisfaction of the person's biological, psychological, social, and cultural needs" (Proshansky et al. 77).
} 
'settled area'." Significantly, the frontier stood for the evolution of the American character and institutions, by way of the European settlers' confronting and adapting to the wilderness:

The frontier is the line of most rapid and effective Americanization. The wilderness masters the colonist. It finds him a European in dress, industries, tools, modes of travel, and thought. It takes him from the railroad car and puts him in the birch canoe.... It puts him in the log cabin of the Cherokee and Iroquois and runs an Indian palisade around him. Before long he has gone to planting Indian corn and plowing with a sharp stick; he shouts the war cry and takes the scalp in orthodox Indian fashion. (522, emphasis mine)

Turner's environmental determinism, inflected by the Lamarckian belief in the biological inheritance of mental traits, thought patterns, and behavior, involved a strategic de-evolution to the Native American ways and warfare as a condition of survival (Pettegrew 26, 28). In Turner's evolutionary model, the westward movement, marked spatial and social distance from Europe: "Little by little [the frontiersman] transforms the wilderness; but the outcome is not the old Europe.... here is a new product that is American" (522). Influenced by Herbert Spencer, Turner explained the social evolution of the frontier in terms of invasion and succession (Popper 262). In a manner that resembled species competition for resources and territory, the frontier evolved from pioneer homesteads, through ranches and farmsteads into towns and manufacturing centers. Along with these successive waves of settlement, there allegedly developed American intellectual traits (individualism, strength, buoyancy, or inventiveness), unique social and political institutions, and urban forms (525). "As successive terminal moraines result from successive glaciations," Turner reasoned, "so each frontier leaves its traces behind it, and when it becomes a settled area the region still partakes of the frontier characteristics" (522). Turner's rich metaphoric prose, which compresses several centuries of settlement into a vivid story with a single protagonist and links it to grand geological processes that unfold over millennia, was rapidly absorbed into the nation's cultural imaginary. It infused the project of Westward expansion with the idea of progress, a condition of the nation's existence and providential destiny. ${ }^{3}$

Almost three decades after Turner announced the closing of the frontier, in the 1920s the Chicago School of Sociology attempted to study and describe

\footnotetext{
${ }^{3}$ In the canonical text of the era of Manifest Destiny journalist John L. O'Sullivan wrote: "We are the nation of human progress, and who will, what can, set limits to our onward march? Providence is with us, and no earthly power can" ("The Great Nation of Futurity").
} 
yet another great migration of people in North America, this time from rural areas into the growing Midwestern City on the former frontier. Like plant ecosystems, cities were thought of as natural areas subject to invasion and succession as mapped out onto the industrial metropolis. Human competition for work, housing, and resources reflected in the spatial distribution of urban groups. Robert E. Park, Ernest W. Burgess and Roderick D. McKenzie, key exponents of urban ecology, held that the location and relocation patterns were similar to ecological processes whereby different groups manifested diverse levels of adaptation to the urban environment, with some communities being more successful in their struggle for resources than others. ${ }^{4}$ Urban ecology found class mobility, ethnic displacement and segregation, as well as the attendant socio-spatial hierarchies inherent in urban ecologies (Warf 33; Kuhlke 525; Popper 262). Burgess, who translated Chicago's territorial expansion, land use and settlement patterns into a concentric ring model, held that the city grew outward in "successive zones" with "the tendency of each zone to extend its area by the invasion of the outer zone. This aspect of expansion may be called succession," he went on to explain, "a process which has been studied in detail in plant ecology" (Burgess 156-57).

Much like Turner's frontier thesis, which was challenged by the new West historians for its ethnocentrism, nationalistic bias, omissions, and selectiveness (Limerick 21-22), the Chicago School paradigm fell out of favor for its neglect of the role of economy, planning, public policy and legislation in the sociospatial formation of cities (Kuhlke 526). ${ }^{5}$ This paper does not set out to revise the frontier myth or the biological approach to the study of settlement patterns. Rather, I would like to focus on the way the frontier continues to serve as a metaphor of urban growth and redevelopment, displacement, and succession.

The contemporary frontier is neither a distant, inaccessible space, nor is it located in the interstices between the undomesticated wilderness of the West and the technologically advanced Northeast. It is to be found in every American city afflicted with shifting economies, deindustrialization, and decline. Investigating New York's Lower East Side and SoHo in the mid-1980s and 1990s, geographer Neil Smith drew attention to the recurrent frontier imagery

\footnotetext{
${ }^{4}$ Robert E. Park, Ernest W. Burgess, and Roderick D. McKenzie co-authored The City-a collection of essays laying out the ecological approach of the Chicago Scholars to the study of urban form. Urban ecology was interested in the city and neighborhoods within the city, with a focus on the community level where processes of competition and domination, similar to those of among other species, were taking place. See Peter J. M. Nas, "Social Ecology in Urban Setting."

${ }^{5}$ For a contemporary critique of the Chicago school, see Michael Dear's "Los Angeles and the Chicago School: Invitation to a Debate" (2005).
} 
and style as an inseparable component of gentrification. ${ }^{6}$ What surely added to the popularity of the frontier myth was the election of Ronald Reagan for President. A former Western movie actor, Reagan made the cowboy image a key ideological and aesthetic component of his political persona. Paradoxically, the "the new urban frontier" itself was a product of the Reagan-era growth-oriented neoliberal urban policies. Media and real estate advertising depicted the blighted neighborhoods as a contact zone between urban wilderness and the civilized world, to be settled by determined and entrepreneurial "homesteaders" who would take the risk of "taming the Wild West" in the Eastern city. Referred to as "urban pioneers," the gentrifiers, who are predominantly middle-class and white, became beacons of progress, agents of physical and moral regeneration encoded in the frontier myth. Boutiques and malls sold the "frontier kitsch" and western craftwork such as Indian rugs, longhorn furniture, artificial coyotes, paintings of noble savages and the desert, cattle skins, spurs, and whips, and Santa Fe jewelry. Fashion outposts trading Western wear evoked the frontier creating a fad for bandannas, fringe jackets, and lizard boots (Smith 113-15). In the concluding sections of his influential analysis, Smith states his argument:

In affirming the connection with nature, the new urban frontier erases the social histories, struggles and geographies that made it.... the frontier ideology continues to displace social conflict into the realm of the myth, and at the same time to reaffirm a set of class-specific and race-specific social norms.... the frontier ideology rationalizes social differentiation and exclusion as natural, inevitable. The poor and the working class are all too easily defined as "uncivil," on the wrong side of a heroic dividing line, as savages and communists. The substance and consequence of the frontier imagery is to tame the wild city, to socialize a wholly new and therefore challenging set of processes into safe ideological focus. As such, the frontier ideology justifies monstrous incivility in the heart of the city. (116-17)

While the depth and clarity of Smith's findings may prompt analogous readings of gentrification fiction, Wingfield's Right of Way does not grant unquestioned explanatory power to the frontier myth or urban ecology. His narrators take invasion-succession out of the "safe ideological focus" by deploying imagery and attitudes that oscillate between seriousness and irony, realism, and parody.

\footnotetext{
${ }^{6}$ I explore gentrification at length in Regeneration, Citizenship and Justice in the American City since the 1970s (2016).
} 


\section{PRECIOUS}

The title of Wingfield's volume is ambiguous and provocative, and the play on the multiple meanings of the phrase "right of way" sets the tone for the whole collection. The primary meaning of "right of way" refers to a stretch of land one has the legal right to use or pass through, even though it belongs to someone else. But the tattered YIELD sign in the center of the volume's front cover leads us to another meaning of "right of way," one connected to traffic rules, where one group of traffic users has the right to proceed with precedence over other users ("Right of way," $O E D$ ). Wingfield elevates the latter meaning to the figurative level, as if prompting the readers to ask the question: Who has the right to place in the gentrifying neighborhood? Whose rights take precedence over all other rights? Who or what ultimately decides about population change and mobility in urban neighborhoods?

In what follows, I analyze the way the literary renditions of gentrification in two stories from the collection- "Precious" and the "Right of Way"-rely on the invasion-succession model as a central rhetorical thread establishing connections between human and non-human species in place. I also point to moments where Wingfield's self-conscious and self-ironic narrators challenge the universal "innocence" of the evolutionary and ecological explanations, as well as the mythical quality of the frontier imagery whose "blissful clarity" "abolishes the complexity of human acts" (Barthes 143). ${ }^{7}$

"Precious" is a short story narrated in the first person by a white male gentrifier, a novice restaurateur, a hen-pecked husband to his second wife Harriet, and a soon-to-be father. The plot of the story revolves around his pursuit of a dog by the name of Precious, whose unruly behavior serves as a pretext for a street-level tour of the gentrifying Cleave Springs, once a thriving black and Italian working-class neighborhood in metropolitan Washington, D.C., built around a prosperous railyard that has suffered from industrial decline, disinvestment, and foreclosures. The use of the word "cleave" in the name of the neighborhood captures the socio-spatial dynamics of gentrification, namely the antithetical nature of the processes in question: on the one hand, "cleave"

\footnotetext{
${ }^{7}$ I am referring to Roland Barthes's definition of myth as depoliticized speech which "purifies [things], it makes them innocent, it gives them a natural and eternal justification; it gives them a clarity which is not that of an explanation but that of a statement of fact... myth acts economically: it abolishes the complexity of human acts, it gives them the simplicity of essences, it does away with all dialectics, with any going back beyond what is immediately visible. It organizes a world which is without contradictions ... wallowing in the evident, it establishes a blissful clarity: things appear to mean something by themselves (Mythologies 143).
} 
stands for the act of separating by dividing, usually with a cutting blow; on the other, it describes attachment or clinging to an object, a place, a person, or a principle ("Cleave, v.1," "Cleave, v.2").

As successive waves of settlers in Cleave Springs reinscribe the urban fabric with new meanings, the old-timers separate from the meaningful place and make room for the newcomers, who are set on making an emotional investment in the place. The white middle-class gentrifiers, accompanied by their pedigree dogs and cats with sophisticated names such as Athena, replace the neighborhood's black residents who move to more affordable suburban locations, such as Prince George's County, taking with them their mongrel dogs with compensatory-sounding names like Precious.

What starts off as the narrator's attempt at helping a black woman catch a "strange looking dog: needle-nosed, bat-eared, with collie-sized body and stubby dachshund legs" (1) and an opportunity to earn the trust of an old-time resident, evolves into a story of Cleave Springs' socio-spatial reinscription. Chasing Precious, the narrator first crosses a "transitional" neighborhood immediately adjacent to Cleave Springs that displays frontier-like qualities and urban grit: "The new taqueria and a pair of antique stores face a sealed up storefront, a failing laundry, a soup kitchen where homeless men chase sermons with meals" (6). Yet just a block away the narrator enters Brimsleaa Salvadoran neighborhood which he perceives as an untamed urban "wilderness." Off-limits to "invasion" by urban pioneers, Brimslea is tainted by racial, linguistic and olfactory exoticism much like Turner's wilderness. The narrator observes a Spanish-speaking "thriving legion of tough, diligent people," descended partly from the indigenous Amerindian population, and "a strong fish odor that wafts out from the Feria del Pescado" (8-9). Far from a welcoming place, the overgrown courtyard of the apartment complex in Brimslea where the narrator corners Precious contrasts with the manicured yards in front of Cleave Springs' renovated houses: "The grass in the [Brimslea] complex is weedy and long. The stucco is moldy; brown paint peels from the trim.... Clumps of ratty crepe myrtle grow here and there" (9).

Much like Turner's frontier which was succeeded by more mature settlement forms, the Cleave Springs area "partakes of the frontier characteristics" but the Brimslea yard, cast as an urban wilderness, "strips off the garments of civilization and arrays [the urban pioneer] in the hunting shirt and the moccasin.... He must accept the conditions which it furnishes, or perish (Turner 522). The dog chase, leading to the confrontation between the narrator and the dog, exemplifies in a parodic fashion a stage in the de-evolutionary process that 
Turner described in all seriousness. As the dog approaches the transitional zone, it drops its leisurely trot and the smile on its face; by the time it reaches Brimslea, its domesticated manner gives way to a wild and ferocious behavior, as if she were transformed by the coarseness of the physical environment: "Precious snaps at me once before darting away. I rear from the dog's strike and note the sound of canine teeth clicking together... a defiant growl rises from the throat" $(6,9)$. As the chase progresses, the narrator becomes agitated and surprisingly "pleased somehow by this hint of danger" (6), running and then "settl[ing] back into my wolf-lope" (7). Dressed in jeans and moccasins, which evoke frontier grit, he eventually takes off his sweaty shirt and uses it to swaddle his arm and turn it into a "wrapped paw raised for defense" (10). The narrator zoomorphically characterizes himself as an aggressive animal getting ready to attack, but also a daring and combative fighter who "assumes the wrestler's pose" as he gets in touch with his primitive instincts:

I lunge forward. Precious bounds to meet me, leaps at my throat and clamps fiercely on the swaddled hand I raise in her path. A sudden heat there, fangs piercing through layers of cloth and skin, probing deep enough to tap the dark energy that once guided me.... As I did then, I yell like a barbarian now, loud and long, clutch the animal's haunch with my free hand and raise both arms high above my head, the squirming body splayed over in my reaching hands like a child being offered up for sacrifice. (10, emphasis mine)

The use of action verbs (bounds, leaps, clamps, probing, yell, clutch) energizes the passage turning a scuffle with a small dog in the Washington, D.C. street to a primal battle worthy of the Frontier.

The narrator's use of self-ironic hyperbole "I yell like a barbarian, loud and long" echoes Turner's de-evolutionary primitivism of the frontiersman who "shouts the war cry and takes the scalp in orthodox Indian fashion." With ever more violent scenarios rushing through his head on how to subdue the violent creature, the narrator emulates predatory instinct. This rewards him with a temporary sense of prowess, virility, and independence. He relishes being beyond the reach of his controlling wife and the haunting voice of his ever-displeased mother, both associations linking femininity to the emasculating qualities of civilization. If Cleave Springs is Harriet's territory where he has lost touch with "the actual me," the wilderness of Brimslea and the primitive violence that the place rekindles - "feet planted on the ground, legs spread apart, back straight, chest bare and heaving, sweat streaming down my body, blood 
beginning to trickle down one of my raised arms" (11)—allow for a temporarily masculine regeneration. ${ }^{8}$

To augment the mythical quality of gentrification as urban frontier, the first-person narrator in "Precious" invokes the utopia of the Western film, the main street of High Noon's final scene where the town sheriff, played by Gary Cooper, singlehandedly fights and victoriously defeats a gang of villains. The narrator uses the distancing tool of irony to inscribe the fight scene with mythical quality. One of the most telling moments in the story is when he becomes aware of his unwanted presence in the Brimslea natives' territory:

Precious in a corner, preparing for the last stand. I laugh at the High Noon drama of it and glance up at one of the young Salvadorans in his window, then another. I am fishing for signs of humor or sympathy. Both men show me faces of stone.... Faces appear in several more windows now: older men, a few women, children of all ages. I am the entertainment. (9, emphasis mine)

It seems that the Western cowboy imagery functions as a decoy to introduce a rupture in the gentrification-as-urban frontier discourse. An overwhelming realization of the emotional chasm, most likely expressing tension, distrust, or even hostility, makes it impossible for the myth to sustain itself. If the analogy to High Noon were to hold true, the narrator would have to accept his villain status, with the dog as a counterpart of the classical Western hero, an outsider who defends the Brimslea natives against yet another gentrifier who sets out to conquer the urban wilderness. ${ }^{9}$

\section{RIGHT OF WAY}

Wingfield's new urban frontier and its human and non-human actors bear traces of the wilderness. "Right of Way" is another story in Wingfield's collection that captures Cleave Springs' dynamic socio-spatial reconfiguration. Focalized through a white West Coast gentrifier, a pregnant woman named

\footnotetext{
${ }^{8}$ In Gunfighter Nation Richard Slotkin writes that the fad for Western ranches among urban elite men, such as Owen Wister and Theodore Roosevelt, was tied to the belief in the West's regenerative power which "by awakening the primal racial vigor of metropolitan aristocrats and by arousing a desire for mastery and conquest and achievement ... would offset the contemptible and enervating imperatives of a commercial society" (Gunfighter Nation 171).

${ }^{9}$ I am relying here on Will Wright's analysis of the classical Western.
} 
Nita, this story also sets up the wild vs. civilized binary that anchors gentrification in the evolutionary dynamic of Turner's frontier thesis.

Upon first meeting Ash, a teenage boy living next door with his junkie mother, Nita describes him as "ugly," having "an abject posture" with "dank hair [hanging] like seaweed from his head" (108-9). After Nita and her husband Wright hire the boy to help them unload the U-Haul truck, she becomes acutely aware of Ash's "odor [which] included scalp oil, sweat, stale smoke, substantial amounts of plain dirt... something dank and sewery that she could not quite place. The whole house reeked of him" (111). As if the nauseating smell were not enough, Ash has got "mossy teeth" (126) and eats like an animal. The choice of verbs used to describe Ash's unmannered eating is telling of the cultural/civilizational chasm separating the artistic San Francisco couple from the native of Cleave Springs: "He hunched forward and wolfed the food fiercely, downing half-sandwiches with quick double-bites, gnashing chips, gobbling handfuls of grapes and clearing the salt and juice from his face with swipes of his grimy arms" (111).

Living in a house with mold on the walls and rotten woodwork, Ash seems out of place in the gentrifying neighborhood. He is always alone, bound for or coming back from the fenced-off right of way, a strip of urban wilderness separating Cleave Springs' parkland - a neatly mowed recreational ground for residents riding bikes and scooters and a dog run-from the highway, and beyond it, a former railyard site gradually reclaimed by nature. A security measure against crime dating back to the early days of gentrification, the untended "frontier belt" is a separate ecosystem where nature holds sway, where invasion and succession are in full swing. The continuous tug-of-war over land and resources resembles the struggle for species competition that inspired the Chicago School of urban ecology: while the bamboo shoots penetrated the fence into the backyards of renovated houses, "trumpet creepers and wisteria and honeysuckle vines that had escaped from back yards [] claimed sections of the right of way" (133). Ash conspires on the side of wilderness by luring the gentrifiers' pet cats with fresh milk right into the claws of a coyote mother who, much like the bamboo shoots, competes for her habitat with domesticated animals. She has seven pups to feed and comes to the right of way on hunting trips from her den on the river beyond the railyard.

Interestingly, while the Chicago School drew heavily on ecological concepts and processes to describe human settlement patterns in the industrial metropolis, the "Right of Way" narrator foregrounds non-human species as 
actants of gentrification. ${ }^{10}$ By transposing the discussion of Cleave Springs' socio-spatial reinscription onto the plant ecosystem, the narrator positions Nita securely as the etic observer of the ongoing invasion-succession process. This is achieved by her ironic distancing, as if she were on the "hither end of free land" (as Turner described the frontier), a mere witness to "the frenzy of warring plants" (133):

A well-worn path led her to a riot of growth, then branched, and kept branching until she couldn't tell the side paths from the main stem and had a hard time keeping track of her general direction. Some of the shrubs and trees and grasses she saw were natives, no doubt, old residents reclaiming habitat wrestled away be people long before. But Nita was a stranger here, an exotic herself, with no way of knowing which plants had historic claims and which were invaders. (133, emphasis mine)

The invasion-succession model becomes a convenient tool for the rendition of the organic growth of the city, including plant and animal ecology. This paradigm has members of individual species competing for space and resources, the stronger species eventually displacing the weaker ones from their habitat. When Nita self-identifies as exotic, she places herself outside the invasion-succession process, but as the narrator fills in the details of Nita and Wright's resettlement, prohibitive real estate prices on the West coast are foregrounded. Their mobility is rooted in economic rationality and seems like a natural adaptation to the existing environment rather than the effect of the broader legal, political, and economic circumstances. Such a natural, individualized approach stands at odds with the Marxist perspective articulated in the capital accumulation theory, which holds that profit-oriented investment, reinvestment, and circulation of capital are the drivers of urban growth and spatial structures (Kuhlke 526). ${ }^{11}$

\footnotetext{
${ }^{10}$ Nature writer Jenny Price explores the tension between culture and nature in the trendy residential neighborhood od Silverlake in Los Angeles, using as a case study coyotes devouring pets. She points to two ways in which the problem was framed in the Los Angeles Times: on the one hand, coyotes were depicted as "urban terrorists" who trespass private property and violate the human settlers' liberties; on the other, coyotes, a species indigenous to the area, were presented as victims of human "invasion," trying to protect their habitat. Looking for a solution to the human invader-animal terrorist logic, she argues for a sustainable approach to urban growth that would be mindful of plant and animal ecologies: "When you use and change a landscape, then the place will respond. Nature is never passive" ("Thirteen ways of Seeing nature in L.A: Part 1").

${ }^{11}$ The capital accumulation theory represents the production explanation of gentrification. A competing scholarly perspective on the causes of gentrification focuses on the gentrifiers' lifestyle preferences and consumer choices. For more, see for example Lees, Slater, and Wyly's Gentrification (2008).
} 
Nita's experience of uprooting herself from the West Coast home is still fresh, while her response to Cleave Springs verges on topophobia-the opposite of the term topophilia, coined by geographer Yi-Fu Tuan to describe "human love of place," "an affective tie with the material environment" which may "vary from the fleeting pleasure one gets from a view to the equally fleeting but far more intense sense of beauty that is suddenly revealed. The response may be tactile, a delight in the feel of air, water, earth" (92-93). Topophobia, by analogy, is connected to negative emotions evoked by places, such as fear, dislike, anxiety, and disgust, constituting responses to one's environment, where "the feeling and its object are often inseparable" (92). While Nita's mood swings and bouts of nausea may be explained away as the work of pregnancy hormones, a reader attentive to the narrator's cues will find an alternative source of her anxiety or disgust. In her interactions with the physical and social environment, she feels like a stranger confined to "the empty living room of an ugly little brick house surrounded by weedy flower beds" (110, emphasis mine). Her experience of the new place is rendered through such physical sensations as sight, smell, and sound, as well as affective and aesthetic responses: the off-putting "fish-belly skin" of Ash's "limp" hand, the disgusting smell that the boy left behind, which made her vomit, the noise of "cicadas [that] sawed in the branches above, a sound that grated in her western ears" (114). But since moving house is equally an opportunity that feeds Nita and Wright's hopes and aspirations, including that of making the destination into "a meaningful space," then an analogous relocation of oldtime residents to affordable locations belongs in the category of the uneventful, the taken-for-granted, "innocent" as a myth, with invasion-succession as part and parcel of the American way of life.

\section{CONCLUSION}

Wingfield expertly uses the imagery of invasion-succession and the frontier to inscribe the most recent patterns of mobility and settlement into the national historiography and mythmaking. Yet he disarms the enduringly seductive myth with ironic distance, using hyperbole and parody. Behind the façade of the frontier myth, Right of Way stories offer a nuanced picture of the micro-level interactions between old-timers and newcomers; they bring out the layered nature of place built of the residue of individual histories, memories, and experiences accumulated across time in space. Like Turner's glacier, which carries with it soil and rocks that it deposits, as it melts, in the terminal 
moraine, successive waves of settlers bring to American neighborhoods aspirations, attitudes, tastes, and behaviors incompatible with those of the oldtime residents. The moraine in Turner's metaphor can be read as layer upon layer of material and immaterial culture - building and gardening styles, food preferences, leisure pursuits, and styles of interaction that accrue to create a specific sense of place. Adaptation to the social and physical environment is not achieved solely through the newcomers' linear progression from topophobia, a fear of place, to topophilia, a love of place, analogous to the evolutionary paradigm structuring the frontier myth. Adaptation is equally about a continuous tension between topophilia and topophobia, two coextensive affective forces inherent in the gentrification process.

\section{WORKS CITED}

Barthes, Roland. Mythologies. 1972. Vintage, 1992.

Burgess, Ernest W. "The Growth of the City: An Introduction to a Research Project.” The City Reader, edited by Richard T. LeGates and Frederic Stout, 2nd ed., Routledge, 1996, pp. 153-61.

“Cleave, v.1." OED Online, Oxford UP, March 2020, www.oed.com/view/Entry/34105. Accessed 14 May 2020.

“Cleave, v.2." OED Online, Oxford UP, March 2020, www.oed.com/view/Entry/34106. Accessed 14 May 2020.

Cresswell, Tim. "Place." Encyclopedia of Human Geography, edited by Barney Warf, Sage Publications, 2006, pp. 358-56.

Dear, Michael. "Los Angeles and the Chicago School: Invitation to a Debate." Cities and Society, edited by Nancy Kleniewski, Blackwell Publishing, 2005, pp. 54-71.

Dybska, Aneta. Regeneration, Citizenship, and Justice in the American City since the 1970s. Peter Lang, 2016.

Florida, Richard. The Rise of the Creative Class. And How It's Transforming Work, Leisure, Community and Everyday Life. Basic Books, 2002.

High Noon. Directed by Fred Zinneman. United Artists, 1952.

Lees, Loretta, et al. Gentrification. Routledge, 2008.

Kuhlke, Olaf. "Urban Spatial Culture.” Encyclopedia of Human Geography, edited by Barney Warf, Sage Publications, 2006, pp. 525-27.

Limerick, Patricia Nelson. The Legacy of Conquest: The Unbroken Past of the American West. Norton, 1987.

Nas, Peter J. M. "Social Ecology in Urban Setting." Encyclopedia of Life Support Systems. www.eolss.net/Sample-Chapters/C11/E1-11-02-05.pdf. Accessed 10 May 2020.

Park, Robert E., Ernest W. Burgess, and Roderick D. McKenzie. The City. U of Chicago P, 1925.

Pettegrew, John. Brutes in Suits: Male Sensibility in America, 1890-1920. Johns Hopkins UP, 2007.

Popper, Deborah. "Invasion-Succession.” Encyclopedia of Human Geography, edited by Barney Warf, Sage Publications, 2006, pp. 262-63. 
Price, Jenny. "Thirteen Ways of Seeing Nature in Los Angeles: Part 1.” The Believer, 1 Apr. 2006, believermag.com/thirteen-ways-of-seeing-nature-in-la/. Accessed 14 May 2020.

Proshansky, Harold M., et al. "Place-Identity: Physical World Socialization of the Self." 1983. The People, Space, and Place Reader, edited by Jen Jack Gieseking and William Mangold, with Cindi Katz et al., Routledge, 2014, pp. 77-86.

"Right of way." OED Online, Oxford UP, March 2020. www.oed.com/view/Entry/165900. Accessed 14 May 2020.

Sack, Robert D. Homo Geographicus. Johns Hopkins UP, 1997.

Slotkin, Richard. Gunfighter Nation: The Myth of the Frontier in Twentieth-Century America. U of Oklahoma P, 1992.

Smith, Neil. "Building the Frontier Myth." The Gentrification Debates: A Reader, edited by Japonica Brown-Saracino, Routledge, 2010, pp. 113-17.

O’Sullivan, John L. "The Great Nation of Futurity.” Democratic Review, vol. 6, no. 23, 1839, pp. 426-30. www.durmushocaoglu.com/data/kutuphane/17_The_Great_Nation_of_Futurity.pdf.

Tuan, Yi-Fu. Topophilia. A Study of Environmental Perception, Attitudes, and Values. Prentice Hall, 1974.

Turner, Frederic Jackson. "The Significance of the Frontier in America." The American Intellectual Tradition: A Sourcebook, edited by David A. Hollinger and Charles Capper, vol. 1-2, Oxford UP, 1989, pp. 521-25.

Warf, Barney. "Neighborhood Change." Encyclopedia of Human Geography, edited by Barney Warf, Sage Publications, 2006, pp. 325-26.

Wingfield, Andrew. Right of Way. Washington Writers' Publishing House, 2010.

Wright, Will. "The Structure of Myth \& The Structure of the Western Film." Cultural Theory and Popular Culture: A Reader, edited by John Storey, Pearson Prentice Hall, 2006, pp. 293-302.

Zukin, Sharon. Naked City. The Death and Life of Authentic Urban Places. Oxford UP, 2010.

\section{METAFORYKA POGRANICZA W CYKLU OPOWIADAŃ ANDREW WINGFIELDA PT. RIGHT OF WAY (2010) POŚWIĘCONYCH PROCESOM GENTRYFIKACJI}

$$
\text { Streszczenie }
$$

Niniejszy artykuł stanowi analizę cyklu opowiadań pt. Right of Way (2010) amerykańskiego pisarza Andrew Wingfielda przez pryzmat mitu pogranicza. Odwołując się do pojęcia pogranicza, sformułowanego przez historyka Fredericka Jacksona Turnera pod koniec XIX w. oraz do teorii miejskiej ekologii wypracowanej przez socjologów tzw. szkoły chicagowskiej, pokazuję w jaki sposób Wingfield wykorzystuje metaforę pogranicza i proces inwazji-sukcesji w celu krytycznego ujęcia gentryfikacji w podmiejskiej Ameryce. Wingfield sięga po rozpoznawalny dla Amerykanów mit założycielski, ale zabieg ten służy mu jako punkt wyjścia do wielowymiarowego ujęcia zmian zachodzących w przestrzeni miejskiej. Interesują go przede wszystkim interakcje międzyludzkie w obrębie lokalnej wspólnoty oraz tworzenie się więzi emocjonalnej z miejscem.

Słowa kluczowe: mit pogranicza; gentryfikacja; proces inwazji-sukcesji; ekologia miejska; przywiązanie do miejsca. 